\title{
The Effects of Tax Incentives on Firm Performance: Evidence from Uganda
}

\author{
Stephen Mayende ${ }^{1}$ \\ ${ }^{1}$ School of Economics, Makerere University, Kampala, Uganda \\ Correspondence: Stephen Mayende, School of Economics, Makerere University, Kampala, Uganda. Tel: \\ 25-677-244-3392. E-mail: stepmayende@yahoo.co.uk
}

Received: August 2, 2013 Accepted: September 2, 2013 Online Published: November 29, 2013

doi:10.5539/jpl.v6n4p95 URL: http://dx.doi.org/10.5539/jpl.v6n4p95

\begin{abstract}
This paper attempts to analyse the effects of tax incentives on the performance of Ugandan manufacturing firms in terms of gross sales and value added employing panel data estimation techniques. The study findings show that firms with tax incentives perform better in terms of gross sales and value added than their counterparts. The education level of managers of firms, firm-size, and age of the firm have positive impact on firm performance. The major policy implication of the study findings indicates that Government needs to streamline the provision of tax incentives for better firm performance. Access to quality and technical education and skills development is necessary in order to have qualified managers with high level of management skills to utilize the available tax incentives so as to improve firm performance.
\end{abstract}

Keywords: tax incentives, firm performance, Uganda

\section{Introduction}

The 2001 Organization for Economic Co-operation and Development (OECD) Tax policy study defines tax incentives as: "provision in the tax code or other codes that offer a preferential tax treatment to certain activities over time, for example manufacturing versus non-manufacturing industries, some organizational forms of business over others (i.e. incorporated versus unincorporated)". Easson and Zolit (2003) define tax incentives as: "those special exclusions, exemptions, or deductions that provide special credits, preferential tax rates or deferral of tax liability". They argue that tax incentives can take the form of tax holidays for a limited duration, current deductibility for certain types of expenditures, or reduced import tariffs or customs duties.

In 1987, the Government of Uganda embarked on an economic recovery program comprising of fiscal and monetary reforms. Uganda's tax system was significantly transformed from a system previously characterized by exceptionally high tax rates, multiple rates structures, wide range of discretionary tax exemptions and a very weak tax administration. The major reforms undertaken since 1987 involved the creation of Uganda Revenue Authority in a bid to improve tax administration (URA Statute No. 6 1991). In the same year, Uganda Investment Authority (UIA) was created to promote and facilitate investments in the country (The Investment Code 1991, Statute No. 1). The Investment code provided a number of incentives which included: exemption of investors from import duties and sales taxes, issuing of certificate of incentives, drawback of duties and sales tax payable on imported inputs used in producing goods for exports and easy accessibility to credit from domestic sources by foreign investors among others. Tax incentives were introduced to compensate firms that undertook major investment projects for the prevailing market distortions (Reinika \& Chen, 1999).

The Regional Program on Enterprise Development (RPED, 2003) survey on Investment Climate in Uganda identified initial firm size, human capital, sources of finance to start up, nature of firm's acquisition and government fiscal policy such as high tax rates among others as key factor that influence firm growth. The survey also found out that taxation was one of the main obstacles to firm's growth. This justifies the role of tax incentives in improving firm's output.

The Government of Uganda has been implementing a number of tax incentives since the Investment Code was enacted by Parliament in 1991. The Government offers tax incentives to new or expanding business enterprises in order to encourage the private sector to increase their investments as well as attracting more private business entrepreneurs into the economy. The tax incentives are in form of tax holidays, initial capital allowances, 
withholding tax exemption, Value Added Tax (VAT) reductions, income tax rates reductions, and preferential tax rates, carry forward losses and import duty exemptions among others. The Government offers tax incentives with different objectives which include correction of market imperfections faced by firms, reductions of transaction costs of firms, regional development and prioritized investments among others. Tax incentives can have positive or negative impact on performance of firms when being implemented which also affect the tax effort for the country. Since the introduction of tax incentives in Uganda, their effect on performance of firms in terms of gross output (sales) and value added is not known.

The objective of this study is to analyse the effect of tax incentives on firm performance in terms of gross sales and value added. The study attempts to provide answers to the following key pertinent research questions: Labour and Capital have positive relation with firm performance and firms with tax incentives perform better than their counterparts. This study utilizes the 2000-2002 World Bank data under Regional Program on Enterprises Development (RPED, 2003), which is the only available comprehensive data system on firms in Uganda. The tax incentives identified were exemption of import duty and withholding tax under section 140 of the Customs Act. Some of the firms did benefit from these tax incentives while others did not.

This study deviates from the previous studies (Bernstein \& Shah, 1994; Shah \& Baffes, 1995) in that, this study considers import duty and withholding tax as tax incentives but not investment tax credits, investment allowances, accelerated capital consumption, and corporation tax rates. In addition, this study provides comprehensive evidence on the extent to which tax incentives affect manufacturing firms' performance in terms of their gross sales and valued added in Uganda by applying robust panel econometric methods. Furthermore, the study provides an informed basis for taking action on tax policy by government of Uganda in addition to filling the gap about what is not known about effects of tax incentives on performance of firms. The results of the study are useful to tax collectors, policy makers and stake holders who formulate or evaluate tax incentive programmes. As for policy makers it can be used as a tool for investment promotion in an effort to foster economic development. In regard to policy makers, the findings will guide them to design appropriate tax laws and regulations to promote the manufacturing sector in Uganda.

This paper is structured as follows. Section 2 presents the related literature reviewed. The methodology applied is presented in section 3. The results are discussed in Section 4 and Section 5 provides the concluding remarks and policy recommendations.

\section{Theoretical Background}

A number of studies show the influence of taxation on business production and investments decision in developing countries. Bernstein and Shah (1994) provide an empirical framework for assessing the effects of tax policy on an array of producer decisions about output and input demands in Mexico, Pakistan, and Turkey. Their results suggest that tax policy affects production and investment and those selective tax incentives such as investment tax credits, investment allowances, and accelerated capital consumption (depreciation) allowances are more cost effective at promoting investment than more general tax incentives, such as corporate tax rate reductions. The long-run cost-effectiveness of these incentives, except corporate tax rate reductions, which proved cost- ineffective in all cases, varies by country. In Turkey, investment allowances and capital consumption allowances neither were cost-effective, while in Mexico neither the investment tax credit nor accelerated capital consumption were cost effective. Also it was revealed that the investment allowances and accelerated capital consumption allowances available to Turkish industries proved cost-effective. Implication of this finding is that the country must take investment tax credits refundable and permit investment and depreciation allowances to be carried forward. The authors argue that if stimulation of investment expenditure is the sole objective of tax policy, the reduction of the corporate tax rate is not a cost-effective instrument by which to achieve this objective.

Shah and Baffes (1995) in their study on Pakistani manufacturing industries conclude that investment tax credits and reductions in corporate tax rates were not cost-effective, whereas a full expensing option for Research and Development (R\&D) was cost effective. Rajagopal and Shah (1992) conclude that sample industries had limited market power and were to shift taxes forward to consumers only partially. They note that the effect of tax incentives varied greatly across different industries and only in three cases did tax incentives prove cost-effective in the short run. Banerjee and Duflo (2005) revealed that Government may over protect some investors and under protect others, resulting in productivity difference among firms. They identify that excessive government intervention, related to a high degree of formalization or burden-some legal procedures, may create barriers to entry growth and protect inefficient incumbent firms. At the same time lack of appropriate regulations regarding property rights and legal enforcement may discourage investment. Credit constraints in poorly developed financial markets likewise result in unequal access to finance, misallocation of capital and productivity differences. Tybout 
(2000) mention the uncertainty about government policies and demand condition, poor rule of law, and corruption as important factors hampering the operations of firms. Also, Eifert et al. (2005) found that high indirect costs due to high transportation and utility costs, bribes, security among others and business environment related losses depress productivity of African firms.

Biggs (2007) indicates that fiscal incentives may have only a limited impact in some cases. In addition, Morisset and Pirnia (2000) conclude that tax exemptions can influence some of the investors, some of the time, but are generally only marginal factors. Also, they note that "Tax exemptions are like a desert; it is good to have, but it doesn't help very much if the meal isn't there". Also, Lall (2000) argues that in a survey of Taiwanese firms, only $8 \%$ of firms rated tax incentives as the single most government policy for promoting technological development, educating more R\&D personnel (18.8\%), coordinating firms to conduct joint research (18.6\%) and introducing new technology from abroad (17.2\%).

Penrose (1959) argues that the firm is a coherent administrative organization where managerial resources are critical. It is the manager's entrepreneurial skills that provide the inducement for growth and determine the rate of expansion. The author argues that managers are not primarily interested in profitability, but in the profitable expansion of the activities of their firms. In the long run, the profitability, the survival and the growth of a firm do not depend so much on the efficiency the firm organizes its production, but on its ability to detect external opportunities and threats and align internal resources to take advantage of the expected business environment.

\section{Methodology}

Following Asteriou and Hall (2007), this study employs a Cobb-Douglas production function. It is argued that one of the most basic relationships in economic theory is the production function that, usually, relates output (denoted by Q) to possible factor inputs affecting production, such as labour $(L)$ and capital $(K)$. The decision to produce and the combination of inputs to use is often an economic one (Wallis, 1979). Production technology and factor prices determine the cost of production (Pindyck \& Rubinfeld, 1998). Therefore, the main purpose of a production function is to provide the technical relationship between the inputs and the outputs necessary for attaching cost to the different input combinations to aid in making economic decisions. The general form of this relationship is expressed by:

$$
Q_{t}=f\left(K_{t}, L_{t}\right)
$$

From Equation 1, $Q_{t}$ is firm output produced in period $t$ using the different factor combination of $K$ and $L$. A production process focuses on the relationship between the physical units of output and inputs. According to Asteriou and Hall (2007), a frequently utilized form of a production function due to its properties is the Cobb Douglas production function expressed by:

$$
Q_{t}=A K_{t}^{\alpha} L_{t}^{\beta}
$$

From Equation 2, where $\alpha$ and $\beta$ are constant terms that express the responsiveness of output to capital and labour respectively. $\boldsymbol{A}$ can be regarded as an exogenous efficiency/technology parameter. Therefore, the greater the $\boldsymbol{A}$, the higher is the maximum output keeping labour and capital constant. The Cobb Douglas production has the property of constant returns to scale if $\alpha+\beta=1$. That is, if $\mathrm{L}$ and $\mathrm{K}$ are each increased by $20 \%$, then $\mathrm{Q}$ increases by $20 \%$. Returns to scale refers to a technical property of production that examines changes in output subsequent to a proportional change in all inputs (where all inputs increase by a constant factor). In addition, if output increases by less than that proportional change, there are decreasing returns to scale i.e., $\alpha+\beta<1$ whereas if output increases by more than that proportion, there are increasing returns to scale i.e., $\alpha+\beta>1$.

The Cobb-Douglas production function is augmented by adding more explanatory variables to reflect the production features of the Ugandan manufacturing firms. Included are variables like raw materials, fuel, land, unskilled labour, skilled labour, plant and machinery, real money balances, etc, besides labour and capital (Intrilligator et al., 1996; Khan \& Ahmad, 1985). The restrictive assumption of constant returns to scale is relaxed to allow either decreasing or increasing returns to scale. Further the Cobb-Douglas function is utilized in this study because of its simplicity and when is transformed into logarithms, one obtains a model that is linear in inputs and is thus straightforward to estimate. Secondly, in Uganda, an augmented Cobb-Douglas production function was utilized in the Investment Climate assessment (World Bank, 2003).

Production functions are nonlinear and are usually transformed into log linear functions for easy estimation using most of the available estimation methods such as Ordinary least squares and the widely used production function is Cobb Douglas with some modifications Fraser (2002). In this regard, we employ the modified Cobb Douglas function given by the following specification: 


$$
Q_{i t}=A L \underset{i t}{\stackrel{\alpha}{\alpha}} K_{i t}^{\beta} T_{i t}^{\gamma} C_{i t}^{\delta} Z_{i t}^{\phi}
$$

From Equation 3, $\mathrm{Q}_{\mathrm{it}}$ is output proxied by gross sales/value added for firm I at time $t$. A is efficiency parameter, $K_{\mathrm{it}}$ is capital, $L_{\mathrm{it}}$ is labour, $T_{\mathrm{it}}$ is a dummy variable for tax incentive, $C_{\mathrm{it}}$ is cost of production and $Z_{\mathrm{it}}$ is a vector of firm specific variables. Capital stock is defined in terms of plant machinery plus building. Labour is defined in terms of expenses on wages and salaries. Valued added is calculated from the data as the difference between value of gross sales and cost of raw materials. Cost of production includes raw materials, energy, financial and overhead costs.

Equation number 3 is translated into natural logs to obtain the following expression:

$$
\operatorname{In} Q_{i t}=C_{0}+\alpha \operatorname{In} L_{i t}+\beta \operatorname{InK} K_{i t}+\gamma \text { Taxincentive }+\ln \operatorname{Cost}_{i t}+\phi Z_{i t}+\eta_{i}+\varepsilon_{i t}
$$

From Equation $4, \ln Q_{i t}$ is the $\log$ of gross sales/value added by firm $i$ at time $t$ and $C_{0}$ is a constant. Tax incentive is a dummy variable, whereby by it is equal to 1 if firm I at time $t$ received tax incentive and zero otherwise. Also $\ln L_{i t}$ is $\log$ of labour; $\ln K_{i t}$ is $\log$ of Capital stock and $\ln$ Cost $_{i t}$ is $\log$ of cost of production. $\ln$ Cost $_{i t}$ is included as an explanatory variable when output proxied by sales is the dependent variable. However when value added is the dependent variable, it is excluded to avoid multicollinearity. $Z_{i t}$ is vector of firm-specific variables which include: level of education of managers i.e. holder of degree, vocational, secondary and primary, age of the firm, type of sector i.e. commercial agriculture, manufacturing, service and construction, size of firm in terms small firm, medium and large (small firm employing less than 20 workers, medium firm employing 20-99 workers and large firm employing more than 100 workers), experience of owners of the firm in working in foreign firm or foreign managed firm (dummy 1 if owners of firm have experience and zero otherwise) and ownership i.e. domestic or foreign or joint, $\eta_{i}$ is the firm specific effect (unobserved firm heterogeneity) that reflects firm efficiency and managerial skills and $\varepsilon_{i t}$ is a random disturbance term assumed to be distributed identically and independently across the firms. It represents factors such as luck, weather conditions and unpredicted variations in inputs.

Production function can be estimated by applying either the fixed effects estimator (FE) or the random effects estimator (RE), Greene (2003). The choice depends on the test developed by Hausman in 1978. The random effects estimator model has advantage over the fixed effects estimator is that it allows for explanatory variables that are constant over time, yet the same get swept away under fixed effects transformation. Therefore this study applies the random effects estimator due to the time-invariant explanatory variables.

\subsection{Data}

The study used secondary data collected by the World Bank under Regional Program on Enterprises Development for the years 2000-2002 in collaboration with Uganda Manufacturers Association Consultancy and Information Services (UMACIS).The survey covered 392 firms for the period 2000-2002 across four sectors (commercial agriculture, construction, manufacturing and tourism). The majority of the firms were manufacturing ones. The survey covered a wide range of information on the establishments which included basic information on legal status, year of registration, firm size, year of starting business location, forms of firm ownership in terms of foreign and domestic, firm gross sales, stocks, capacity utilization, share of output exported, raw material costs and various types of expenses, labour costs in terms of salary and wages, capital stock and investment, level of education of managers and sources of investments undertaken. A list of firms which had incentives was obtained from Uganda Revenue Authority. The study utilized data on gross sales, cost of raw materials, capital stock, labour force employed, wages and salaries, cost of production (measured in Ugandan shillings), sector of the firm, ownership of the firm, ages of firms, and education levels of managers. Panel data was utilized.

\section{Results}

\subsection{The Results of the Descriptive Statistics}

Table1 presents the descriptive statistics of the dependent variables and the explanatory variables. The descriptive statistics indicate the mean $\log$ of sales as 20.28 , standard deviation of 2.50 , minimum value of 14.47 and maximum value of 26.98 . The mean $\log$ of value added is 19.98 , standard deviation of 2.61 , minimum value of 13.85 and maximum value of 26.79 . The share of firms which received incentives is 15.00 with a standard deviation of 0.35 . The share of managers with university education is 0.48 with a standard deviation of 0.50 . This implies that majority of the managers are university graduates who are able to utilize their skills to increase sales and value added of firms. The mean age of firms is 14 years which indicates that many of the firms are young and able to increase their production in the long run. The mean log of cost of production is 19.19 with a standard deviation of 2.47, minimum level of 13.85 and maximum value of 26.79. The share of large firms is 0.19 and 
medium firms are 0.25 . This implies majority of the firms are small employing less than 20 workers. The share of manufacturing is 0.74 which implies majority of the firms are of manufacturing type.

Table 1. Descriptive statistics of explanatory variables

\begin{tabular}{llllll}
\hline Variable & $\begin{array}{l}\text { Observati } \\
\text { on }\end{array}$ & Mean & $\begin{array}{l}\text { Standard } \\
\text { Deviation }\end{array}$ & Minimum & Maximum \\
\hline Log sales & 510 & 20.28 & 2.50 & 14.47 & 26.98 \\
Log of capital & 510 & 17.54 & 2.57 & 12.62 & 25.56 \\
Log labour & 510 & 17.32 & 2.06 & 12.21 & 23.05 \\
Incentives & 510 & 0.15 & 0.35 & 0.00 & 1.00 \\
Secondary Education & 510 & 0.16 & 0.37 & 0.00 & 1.00 \\
Vocational Education & 510 & 0.26 & 0.44 & 0.00 & 1.00 \\
University Education & 510 & 0.48 & 0.50 & 0.00 & 1.00 \\
Age of firms & 510 & 14.25 & 17.52 & 0.00 & 92.00 \\
Medium firm & 510 & 0.25 & 0.43 & 0.00 & 1.00 \\
Large firm & 510 & 0.19 & 0.39 & 0.00 & 1.00 \\
Cost of production & 508 & 19.19 & 2.47 & 11.85 & 26.24 \\
Manufacturing & 510 & 0.74 & 0.44 & 0.00 & 1.00 \\
Agriculture & 510 & 0.19 & 0.40 & 0.00 & 1.00 \\
Services & 510 & 0.02 & 0.15 & 0.00 & 1.00 \\
Construction & 510 & 0.02 & 0.13 & 0.00 & 1.00 \\
Log Value added & 502 & 19.98 & 2.61 & 13.85 & 26.79 \\
\hline
\end{tabular}

Source: Author' tabulation from RPED (2003)

Note: Secondary represents managers with Secondary level of education. Vocational represents managers with vocational level of education; University represents managers who are graduates. Medium represents medium firm size, large represents large firms

\subsection{The Results of the Regression Analysis}

Table $2 \mathrm{a}$ and $2 \mathrm{~b}$ presents the results of pairwise correlation coefficients of the dependent variables gross sales and value added respectively. The level of significance of the correlation coefficient is $5 \%$ in both estimations. Sales represents sales of firms, capital represents capital stock of firms, incentives represents dummy variable for tax incentives, age represents age of firms, medium represents medium firms, large represents large firms and total cost represents cost of production of firms.

Table 2a indicates that a positive correlation between sales for firms and most of the explanatory variables. The level of education of managers with secondary and vocational qualifications has negative correlation with sales. The results show negative correlation between sales with secondary and vocational qualification of managers. For secondary level managers the correlation is insignificant. This implies that managers with low levels of education are not good performers in terms of increasing sales of firms. There is a positive correlation between sales and capital stock with coefficient of 0.11 while correlation between labour and sales is positive and significant. This implies as one increases expenditures on labour, more sales will be realized.

Correlation analysis in Table $2 \mathrm{~b}$ indicate positive correlation between value added and capital stock with coefficient of 0.11 while for labour the correlation is positive and strong with a coefficient of 0.50 . In terms of the level of education of mangers, managers with university degrees have strong correlation with sales and value added than for managers with lower educational levels. The results also indicate that large firms have strong correlation with gross sales and value added as compared to medium firms and small firms. 
Table 2a. Correlation matrix

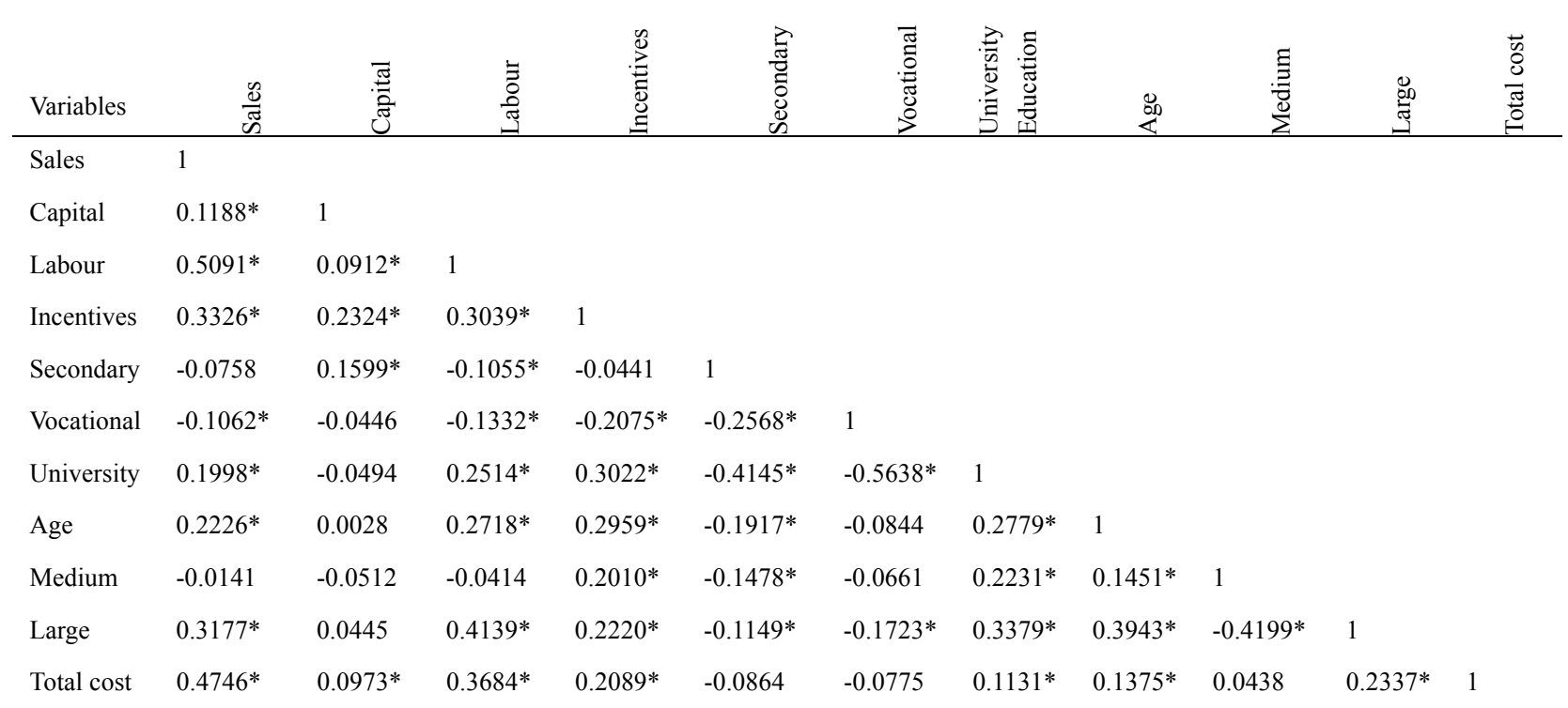

Source: Authors Tabulation form RPED 2003,*means 5\% significance level

Table 2b. Correlation matrix

\begin{tabular}{|c|c|c|c|c|c|c|c|c|c|c|}
\hline Variables & Value added & Capital & Labour & Incentives & Secondary & Vocation & University & Age of firm & Medium & Large \\
\hline Valadded & 1 & & & & & & & & & \\
\hline Capitalstock & $0.1109 *$ & 1 & & & & & & & & \\
\hline Labour & $0.5012 *$ & $0.0912 *$ & 1 & & & & & & & \\
\hline Incentive & $0.3193 *$ & $0.2324 *$ & $0.3039 *$ & 1 & & & & & & \\
\hline Secondary & -0.0712 & $0.1599 *$ & $-0.1055^{*}$ & -0.0441 & 1 & & & & & \\
\hline Vocation & $-0.1034 *$ & -0.0446 & $-0.1332^{*}$ & $-0.2075^{*}$ & $-0.2568^{*}$ & 1 & & & & \\
\hline University & $0.1931 *$ & -0.0494 & $0.2514 *$ & $0.3022 *$ & $-0.4145^{*}$ & $-0.5638^{*}$ & 1 & & & \\
\hline Age & $0.2187^{*}$ & 0.0028 & $0.2718^{*}$ & $0.2959 *$ & $-0.1917 *$ & -0.0844 & $0.2779 *$ & 1 & & \\
\hline Medium & -0.0079 & -0.0512 & -0.0414 & $0.2010^{*}$ & $-0.1478^{*}$ & -0.0661 & $0.2231 *$ & $0.1451^{*}$ & 1 & \\
\hline Large & $0.3045^{*}$ & 0.0445 & $0.4139 *$ & $0.2220^{*}$ & $-0.1149 *$ & $-0.1723 *$ & $0.3379 *$ & $0.3943^{*}$ & $-0.4199 *$ & 1 \\
\hline
\end{tabular}

The empirical analysis begins by estimating an RE log-linear Generalized Least Squares (GLS) with a simple model specification of the Cobb Douglas production function. Two empirical models are estimated to understand the relationship between firm performance and tax incentives. The results are shown in Table 3.

The results in Table 3 indicate that under model 1, capital and labour have positive significant effect on firm performance. The results show that $1 \%$ percentage point increase in capital stock and labour will lead to 0.36 and 0.53 percentage point increase in sales respectively. In addition firms that received tax incentives realized a $0.79 \%$ point increase in performance compared to their counterparts. Therefore, this implies the significance of good deliberate effort to promote industrial development through incentives.

In terms of constant returns to scale, the probabilities for Chi2 are 0.005 and 0.002 , leading to rejection of the null hypothesis of constant returns to scale. Since the sum of the coefficients is greater than one, it implies increasing returns to scale. In addition, the results of model 2 show that the coefficients for capital, labour and tax incentives are all positive and statistically significant at the conventional levels. One percentage point increase in capital 
stock and labour will lead to an increase of 0.34 and 0.64 percentage points in value added respectively. Firms with tax incentives are 0.797 percentage points more productive in terms of value added as compared to their counterparts.

Table 3. Firm performance analysis and tax incentives: regression results

\begin{tabular}{lll}
\hline Variables & Model 1 (Gross sales) & Model 2 (Value added) \\
\hline CONSTANT & $4.593^{* * *}$ & $3.446^{* * *}$ \\
LOG OF CAPITAL & $(0.000)$ & $(0.000)$ \\
& $0.362^{* * *}$ & $0.311^{* * *}$ \\
LOG OF LABOUR & $(0.000)$ & $(0.000)$ \\
& $0.531^{* * *}$ & $0.635^{* * *}$ \\
TAX INCENTIVES & $(0.000)$ & $(0.000)$ \\
& $0.792^{* *}$ & $0.797^{* *}$ \\
\hline R-sq within & $(0.002)$ & $(0.002)$ \\
R square between & 0.002 & 0.003 \\
R.Square & 0.81 & 0.82 \\
No of observation & 0.67 & 0.63 \\
Test for constant returns to scale. & 510 & 502 \\
Walid Value & Chi2 $(1)=7.82$, Prob $>$ chi2 $=0.0052$ & chi2 $2(1)=9.35$, Prob $>$ chi2 $=0.0022$ \\
\hline & Chi2 $(3)=611.4$, Prob $>$ chi2 $=0.000$ & chi2 $(3)=667.87$, Prob $>$ chi2 $=0.000$ \\
\hline
\end{tabular}

Probabilities in parentheses ***Significant at $1 \%,{ }^{* *}$ Significant at $5 \% *$ Significant at $10 \%$

The findings indicate that labour has a greater effect than capital on firm performance. This could be due to the fact that labour skills continue to increase as similar tasks are repeated and this will always lead to efficiency in labour productivity. The results are similar to Jovanovich's (1982) on life-style model where managerial efficiency and learning by doing are the key factors for firm growth. The most efficient firms grow and survive and some of the inefficient ones do not. The effect of capital is less than 0.5 , which implies that there is not much response in the efficiency of capital. Once capital is invested, its performance is affected by depreciation over time. The coefficients of tax incentives are positive and significant in both models which imply that when firms are offered incentives, they become more productive in terms of output and value added than their counter parts. Output from Stata package is shown in annex 1.

Furthermore, we estimate an augmented production function for the Ugandan firms to ascertain which factors are more important in determining firm performance. The results are presented in Table 4 below.

Our results in Table 4 indicate that firms with tax incentives are 0.405 percentage points more productive in terms of gross sales and 0.502 percentage points in terms of valued added than firms with no tax incentives. This result implies that tax incentives play a significant part in enhancing performance among Ugandan manufacturing firms. Therefore, the Ugandan government can promote firm performance by offering tax incentives. An increase in firm sales will provide more employment opportunities on the one hand but on the other, increase the National Income (GDP) and overall tax base in the country. Firms will increase their revenue contribution in terms of Value Added Tax (VAT) and employees will contribute income taxes through "Pay as You Earn" (PAYE) which subsequently increase the tax effort for the country. The study finding is line with Nathan-MSI-Group (2004) who argue that many developing countries offer tax incentives as a way of compensating other deficiencies in the investment climate such as unreliable or high cost of infrastructure, macro-economic instability, or a weak legal and judicial system. They further argue that tax incentives can actually enhance revenue by stimulating investments that will generate other taxable income via employment and linkage effects. 
Table 4. Determinants of firm performance: regression results

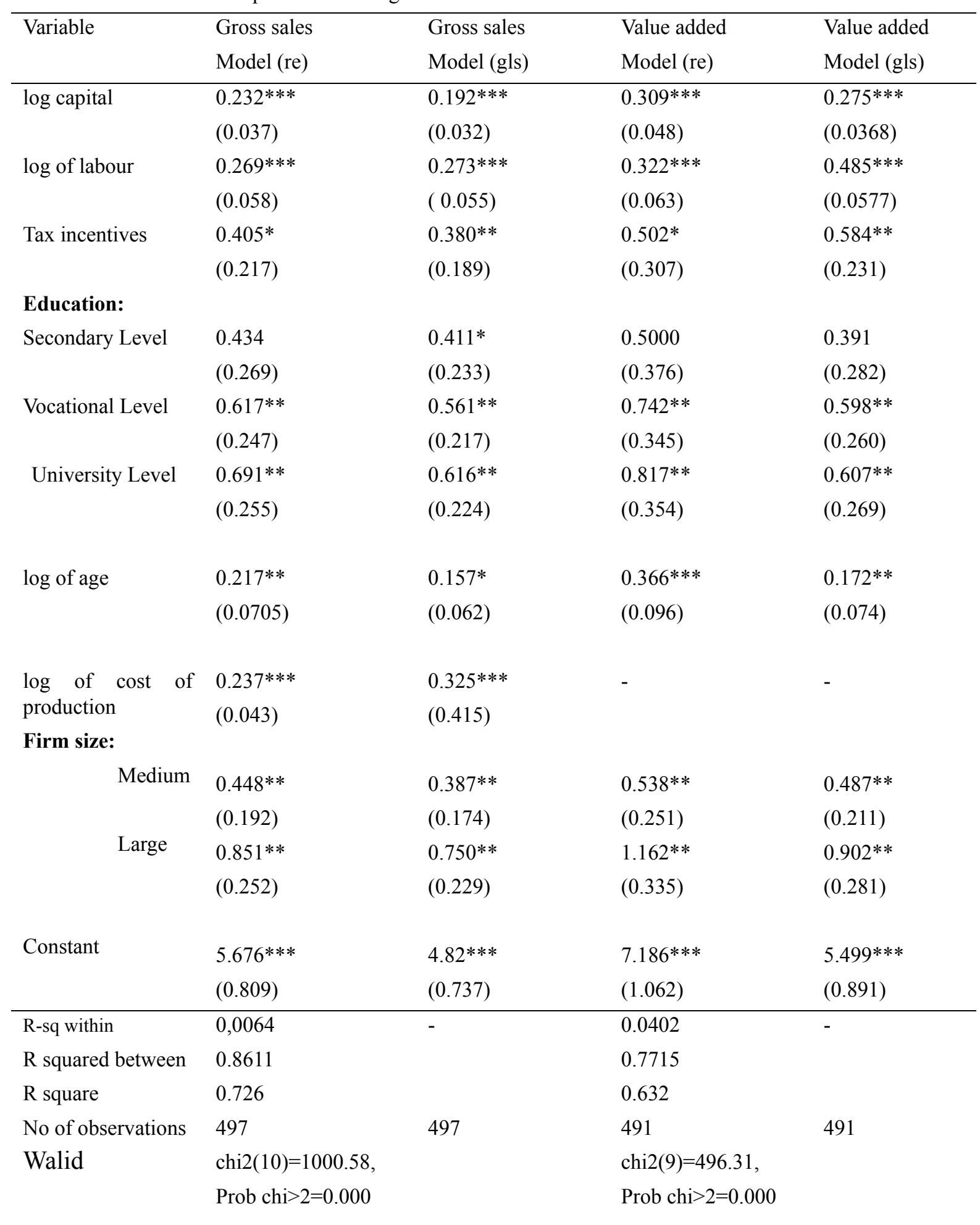

Standard Errors in Parentheses, ***Significant at 1\%, **Significant at 5\%, *Significant at 10\%.

The study finding is also in line with UNCTAD (2000) which points out that Tax incentives may be justified on the grounds of protecting and promoting "infant industries". Therefore to be effective, tax incentives should be directed to small and growing firms. This implies that many small start up firms are often short of funds because of their inability to borrow from Financial Institutions. Many of firms are in non taxpaying situations in the initial years. Incentives employed often determine their effectiveness. 
The results also show that the level of education of entrepreneurs/managers is significant in determining the output and value added firms. Firms headed by managers with university degree are 0.69 percentage points more productive than firms whose managers have primary education. Also firms which are managed by managers with vocational education are 0.617 percentage points more productive than firms whose managers have primary education. Possession of secondary education is not significant in both sales and value models. In terms of value added, a manager with university degree is 0.817 percentage points more productive than a manager with primary education. Firms whose manager has vocational level of education is 0.742 percentage points more productive in terms of value added than firms whose manager has primary level of education. This result implies that highly educated managers are able to understand the importance of tax incentives, use their personal skills and are able to utilize any opportunities available in order to increase firm output and value added. This result is in line with findings of previous studies (Penrose, 1959; World Bank, 2004). Penrose (1959) argues that in the long run, the profitability, the survival and the growth of a firm do not depend so much on the efficiency the firm organizes its production, but on its ability to detect external opportunities and threats and align internal resources to take advantage of the expected business environment.

Furthermore, our results reveal that an increase in firm age by one year will increase gross sales by 0.22 percentage points. In terms of value added an increase of firm age by one year would increase firm performance by 0.37 percentage points. This shows that firm's experience is a very important determinant of gross output and value added. As firms get experience in production of specific products, they utilize the tax incentives available and maximize their outputs. This study finding is similar to Haltiwanger et al. (1999) who found that age of the firm is positively related to its productivity. Shanmugam and Bhaduri (2002) found a positive relation between age and growth firms in the Indian manufacturing sector which is similar to the results of this study.

The results show that an increase in the cost of raw materials by one percent point increases sales by 0.24 percentage points. This implies that when firms maximize the use of their raw material inputs, they are able to maximize their sales by charging higher prices. The results also show that large firms are 0.85 percentage points more productive than small firms. On the other hand, medium firms are more productive than small firms by 0.45 percentage points. This could be attributed to the fact that large firms are able to utilize the tax incentives, manpower skills, economies of scale and available resources to effectively and efficiently increase their output as compared to small ones. This finding is similar to Van (2005) study on a sample of manufacturing firms from nine sub-Saharan African countries where large firms were found to be extremely important since they were able to achieve higher productivity levels and able to survive.

Furthermore, the results reveal a significant effect of the firm's capital and labour on firm performance. The finding indicate that a one percentage increase in the costs of capital and labour would lead to 0.23 and 0.27 percentage points increase in gross sales respectively. For value added, one percent increase in capital stock will increase the value added by 0.31 percentage points, while one percent increase in wages will increase value added by 0.32 percentage points. When firms invest in the capital stock and labour, they are able to increase their gross sales and value added. The results are similar to the World Bank (2003) Investment Climate Assessment report on determinants of firm productivity in Uganda.

The results indicate that as firms get experience in production of different products for different markets, they are able to expand their firm sales and value added. The impact of raw material costs under the random effects estimation is less than under the feasible GLS estimation. This implies that firms which buy their raw materials on periodic basis will incur more costs due to inflation than firms which buy once and stock for production. The impact of frequent purchase of raw materials on firms output will be less as compared to firms which the materials buy and stock at once.

The results in Table 4 show that the coefficient of capital stock is positive and significant in both gross sales and value added models. It can be noted that the coefficient of capital stock is greater under random effects (RE) estimation than under feasible GLS estimation. This implies that investing in capital stock on periodic basis has more impact on sales of firms and value added of firms than investing at once. Labour is one of the most important determinants of firm performance in terms of gross sales and value added. In addition, our results show that labour has less impact on gross sales and value added when applying random effects estimation than under feasible GLS estimation. This is not surprising due to the fact that as firms invest more in capital stock on periodic basis, they become more capital intensive thereby reducing the output contribution by labour. The study finding is similar to the World Bank (2003) Investment Climate Assessment report on Uganda which found out that despite capacity utilization of only 60 percent, every dollar of capital generates twice as much in value added in a year's time as a dollar of capital does in neighboring countries. Furthermore the report points out that largest firms in the region appear to be substituting capital for labor, because of labor laws or a lack of skilled labor. The impact of tax 
incentives is positive and significant under both random effects and feasible GLS estimation. This implies that government incentives given to firms play an important part in promoting firm performance in terms of value added and gross sales which are in line with government strategy of promoting manufacturing.

The results reveal that education is another important determinant of firm performance. We find that education has greater impact on gross sales and value added when applying random effects estimation than feasible GLS estimation. This implies that managers who have higher level of education combined with constant training are able to acquire better skills and increase gross sales and value added of their firms than managers who are trained once in a period. This could be due to periodic training which makes them acquire new skills and be able to perform better. The study finding is similar to World Bank (2003) Investment Climate Assessment report on Uganda show that human capital plays an important part in determining the rate at which firms grow. The findings indicate that firms whose owner-managers have secondary or university degrees grow significantly faster than those whose owner-managers have only a primary education

The coefficients for firm sizes (both large and medium) are greater under random effects estimation than feasible GLS estimation. This implies that large and medium firms are more efficient across time than small firms. Large firms are able to utilize their economies of scale on periodic basis to maximize sales and value added. The study finding is in line with Serrasqueiro et al. (2008) who argue that large firms are more likely to exploit economies of scale and enjoy higher negotiation power over their clients and suppliers. The study finding is also in line with Yang and Chen (2009) who argue that large firms face less difficulty in getting access to credit for investment, have broader pools of qualified human capital, and may achieve greater strategic diversification and be able to perform better that small firms.

The coefficients of determination of 0.63 and 0.73 show that the models adequately explain the relationship of gross sales and value added with the explanatory variables. The probability values or significance levels are almost zero, thereby rejecting the null hypothesis even at the $1 \%$ level that there is a constant return to scale in each model.

\section{Conclusion}

The objective of the study was to examine the effects of tax incentives on performance of Ugandan manufacturing firms using panel data techniques for the period 2000-2002. Our findings indicate that tax incentives have positive impact on firm performance in terms of gross sales and value added. The study also established that firm age and firm size have a positive impact on firm performance. Large and medium firms perform better than small firms. Large firms are able to maximize the economies of scale and increase their output. In addition, the study findings show that the level of education of manager is significant in determining firm performance. Other firm characteristics such as ownership by domestic firm, foreign and joint venture do not affect firm performance. The study finding show that ownership experience in a foreign firm does not affect firm performance.

Our results indicate that the importance to Government to strengthen the provision of tax incentives to firms in an effort to promote development in the manufacturing sector. This requires that provision of tax incentives needs to be transparent, non- discriminatory of ownership of firms and a criterion of accessibility is clear. Comprehensive information on procedures and criteria for obtaining tax incentives under each existing programs need to be frequently availed to the public. This will lead to increased output of different firms and ensure accountability and guard against miss-use of the incentives.

\section{References}

Asteriou, D., \& Hall, S. G. (Eds.). (2007). Applied Econometrics. New York, NY: Macmillian Publishers Limited.

Banerjee, A. V., \& Duflo, E. (Eds.). (2005). Growth Theory through the lens of Development Economics. In Handbook of Development Economics.

Bernstein, J., \& Anwar, S. (1994). Taxes and Production: The Case of Pakistan. International Tax and Public Finance, 1, 227-245. http://dx.doi.org/10.1007/BF00873839

Biggs, P. (2007). Tax incentives to attract FDI. Paper presented at UNCTAD Conference Geneva.

Christopher, K. (2004). Taxation and Investment in Uganda Structure and Trend. Paper presentation to the Business Forum in London, UK for Investment Opportunities in Uganda.

Easson, A., \& Zolit, E. M. (2003). Tax incentives. Paper presented for World Bank course on Practical issues of tax policy in developing countries: 28 April- $1^{\text {st }}$ May.

Eifert, B., Geelb, A., \& Ramachandran,V. (2005). Business Environment and Comparative Advantage in Africa. Evidence from the Investment climate Data, Paper 56. 
Engle, R. F., \& Granger, C. W. J (1987). Co-integration and Error Correction: Representation, Estimation and Testing. Econometrica, 55(2), 251-276. http://dx.doi.org/10.2307/1913236

Flatters, F., \& Emeritus. (2005). International Perspectives on Tax Incentives in Malaysia. Paper Prepared for Malaysian Institute of Taxation National Tax Conference 2005.

Fraser, I. (2002). The Cobb-Douglas Production Function: An Antipodean Defence. Economic Issues, 7(1), 39-58.

Greene, H. W. (2003). Econometric Analysis (5th ed.). Pearson Education International. New Jersey: Upper Saddle River.

Gugl, E., \& Zodrow, R. G. (2006). International Tax Competition and Tax Incentives for Developing Countries. In J. Alm, J. Martinez-Vasquez, \& M. Rider (Eds.), The Challenges of Tax Reform in a Global Economy (pp. 167-191). New York: Springer.

Haltiwanger, J., Lane, J., \& Spletzer, J. (1999). Productivity differences across employers: The roles of employer size, age, and human capital. American Economic Review Papers and Proceedings, 89(2), 94-98. http://dx.doi.org/10.1257/aer.89.2.94

Holland, D., \& Vann, R. J. (1998). Tax law Design and Drafting (Vol. 2, Chapter 23).

Hussain, I., \& Naheed, K. (2005). The effect of Indirect taxation on the manufacturing sector of Pakistan: A case study of shoes Industry. Gomal University Journal of research, 21, 65-67.

Intrilligator, M., Bodkin, R., \& Hsiao, C. (1996). Econometric Models, Techniques and Applications (2nd ed.). North Holland: Prentice-Hall.

Jovanovic, B. (1982). Selection and Evolution of Industry. Econometrica, 50, 649-670. http://dx.doi.org/10.2307/1912606

Khan, A. H., \& Ahmad, M. (1985). Real Money Balances in the Production Function of Developing Country. The Review of Economics and Statistics, 336-340. http://dx.doi.org/10.2307/1924736

Morisset, J., \& Pirnia, N. (2000). World Bank, Working Paper 2509. How Tax policy and Incentives_Affect FDI World Bank Washington.

Musgrave, R. A., \& Musgrave, P. B. (1984). Public Finance in Theory and Practice. New York: McGraw-Hill.

Nathan-MSI Group. (2004). Effectiveness and Economic impact of Tax Incentives in the SADC Region. Technical Report submitted to USAID//RCSA, SADC tax subcommittee, SADC trade, industry, finance and investment Directorate.

OECD. (2001a). Corporate Tax incentives for Foreign Direct Investment. OECD Tax Policy Studies No 4. Paris.

Penrose, E. (1959). The Theory of the Growth of the Firm. New York: Wiley.

Pindyck, R. S., \& Rubinfeld, D. L. (1998). Micro-Economics (4th ed.). London: Prentice-Hall.

Rajagopal, D., \& Anwar, S. (1992). Tax incentive market power and corporate Investment. A rational expectation model applied to Pakistani \& Turkish Industries: Policy Research Working Paper Series 908, The World Bank.

Reinika, R., \& Chen, D. (1999). Business Taxation in a low Revenue Economy. Study on Uganda in comparison with Neighbouring Countries. Africa region Working Paper series No. 3.

Reinikka, R., \& Collier, P. (2001). Uganda's Recovery: The role of Farms, Firms and Government. Kampala Fountain Publishers. http://dx.doi.org/10.1596/0-8213-4664-4

Serrasqueiro, Silva, Z., \& Nunes P. M. (2008). Performance and Size: Empirical Evidence from Portuguese SMEs. Small Business Economics, 31(2), 195-217. http://dx.doi.org/10.1007/s11187-007-9092-8

Shah, \& Baffes, J. (1995). Do tax policies stimulate investment in physical and R\&D capital? In A. Shah (Ed.), Fiscal Incentives for Investment and Innovation. New York: Oxford University Press.

Shah, A. (Ed.). (1990). Fiscal Incentives for Investment in Developing Countries. World Bank.

Shah, A. (Ed.). (1995). Fiscal Incentives for Investment and Innovation. Oxford University Press.

Shanmugam, K., \& Bhaduri, S. (2002). Size, age and firm growth in the Indian manufacturing Sector. Applied Economics Letters, 9(9), 607-613. http://dx.doi.org/10.1080/13504850110112035

Tybout, J. (2000). Manufacturing Firms in Developing countries. How Well Do They Do and why? Journal of Economic literature, 38, 11-44. http://dx.doi.org/10.1257/jel.38.1.11 
UNCTAD. (2000). Investment Policy Review: Uganda. Geneva: United Nations.

Van Biesebroeck, J. (2005). Firm Size Matters: Growth and Productivity Growth in African Manufacturing. Economic Development and Cultural Change, 53(3), 545 -583. http://dx.doi.org/10.1086/426407

Yang, C. H., \& Chen, K. H. (2009). Are small firms less efficient? Small Business Economics, 32(4), 375-395. http://dx.doi.org/10.1007/s11187-007-9082-x 
Annex 1

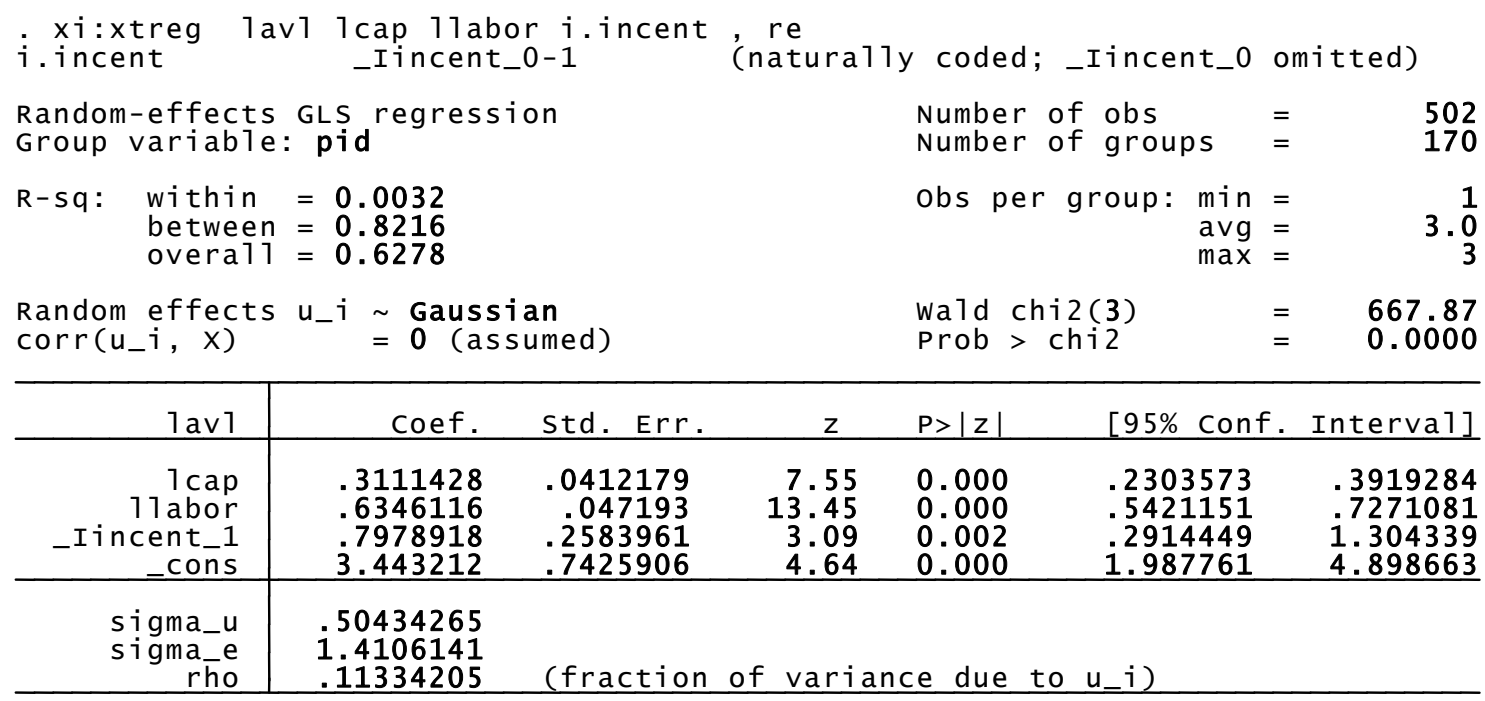

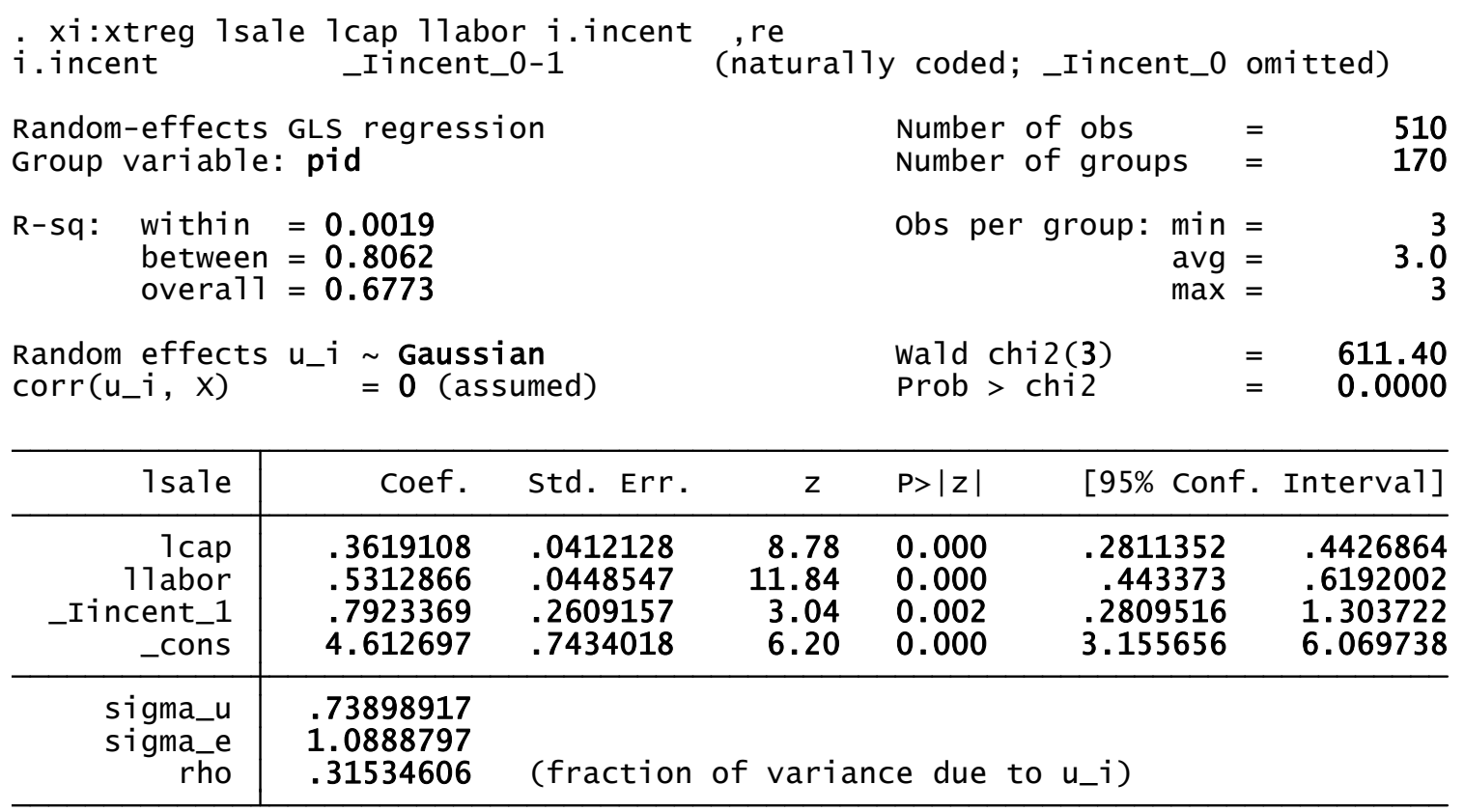

Note: lavl represents log of value added, lsale represents sales, lcap represents log of capital, incent represents tax incentives, cons represents constant.

\section{Copyrights}

Copyright for this article is retained by the author(s), with first publication rights granted to the journal.

This is an open-access article distributed under the terms and conditions of the Creative Commons Attribution license (http://creativecommons.org/licenses/by/3.0/). 